\title{
Catalytic valorization of hardwood for enhanced xylose-hydrolysate recovery and cellulose enzymatic efficiency via synergistic effect of $\mathrm{Fe}^{3+}$ and acetic acid
}

Kaixuan Huang ${ }^{1,2}$, Lalitendu Das ${ }^{3,4}$, Jianming Guo $0^{1,2}$ and Yong $X u^{1,2^{*}}$

\begin{abstract}
Background: Poplars are considered suitable dedicated energy crops, with abundant cellulose and hemicellulose, and huge surplus biomass potential in China. Xylan, the major hemicellulosic component, contributes to the structural stability of wood and represents a tremendous quantity of biobased chemicals for fuel production. Monomeric xylose conversion to value-added chemicals such as furfural, xylitol, and xylonic acid could greatly improve the economics of pulp-paper industry and biorefinery. Acetic acid (HAc) is used as a friendly and recyclable selective catalyst amenable to xylan degradation and xylooligosaccharides production from lignocellulosic materials. However, HAc catalyst usually works much feebly at inert woods than agricultural straws. In this study, effects of different iron species in HAc media on poplar xylan degradation were systematically compared, and a preferable $\mathrm{Fe}^{3+}$-assisted HAc hydrolysis process was proposed for comparable xylose-hydrolysate recovery (XHR) and enzymatic saccharification of cellulose.
\end{abstract}

Results: In presence of 6.5\% HAc with $0.17-0.25 \mathrm{wt} \% \mathrm{Fe}^{3+}$, xylose yield ranged between 72.5 and $73.9 \%$. Additionally, pretreatment was effective in poplar delignification, with a lignin yield falling between 38.6 and $42.5 \%$. Under similar conditions, saccharification efficiency varied between 60.3 and 65.9\%. Starting with $100 \mathrm{~g}$ poplar biomass, a total amount of 12.7-12.8 $\mathrm{g}$ of xylose and 18.8-22.8 $\mathrm{g}$ of glucose were harvested from liquid streams during the whole process of $\mathrm{Fe}^{3+}-\mathrm{HAc}$ hydrolysis coupled with enzymatic saccharification. Furthermore, the enhancement mechanism of $\mathrm{Fe}^{3+}$ coupled with HAc was investigated after proof-of-concept experiments. Beechwood xylan and xylose were treated under the same condition as poplar sawdust fractionation, giving understanding of the effect of catalysts on the hydrolysis pathway from wood xylan to xylose and furfural by $\mathrm{Fe}^{3+}{ }_{-} \mathrm{HAC}$.

Conclusions: The $\mathrm{Fe}^{3+}$-assisted HAc hydrolysis process was demonstrated as an effective approach to the wood xylose and other monosaccharides production. Synergistic effect of Lewis acid site and aqueous acetic acid provided a promising strategy for catalytic valorization of poplar biomass.

Keywords: Poplar, Acetic acid catalysis, $\mathrm{Fe}^{3+}$-assisted hydrolysis, Xylose-hydrolysate recovery, Enzymatic saccharification of cellulose

\footnotetext{
*Correspondence: 1030731413@qq.com

1 Key Laboratory of Forestry Genetics \& Biotechnology (Nanjing Forestry University), Ministry of Education, Nanjing 210037, People's Republic of China

Full list of author information is available at the end of the article
} 


\section{Background}

Plant biomass has been suggested as an abundant and sustainable source for the future chemicals, fuels, and materials due to its carbon-neutral nature and renewability $[1,2]$. Biomass valorization has drawn interest in recent years for processing lignocellulosic fractions via selective hydrolysis routes to release valuable platform chemicals [3]. Poplar sawdust, a wood waste residue after felling, cutting and processing by the furniture factory, is one of the surplus forest residues in China. In general, the wood residues are favorable biomass sources for their superior properties such as high calorific value, low ash content and slagging rate [4]. However, the highly heterogeneous structure can be resistant to effective fractionation into fermentable sugars. Hence, a pretreatment strategy to fractionate poplar sawdust has become a crucial unit operation, to increase the enzymatic digestibility of cellulose whilst leaving out lignin for other economic purposes [5].

Poplar xylan consists of a linear xylose polymer as a backbone with a relatively high content of $O$-acetyl substitutions and 4-O-methyl $\alpha$-D-glucosyluronic acid in the hemicelluloses fractions making it susceptible to the thermal hydrolysis $[1,6]$. Hence, the hydrolysis of poplarassociated xylan primarily produces the pentosan sugar xylose. This xylose can be gathered and co-fermented with glucose to further boost bioethanol production [7]. Alternatively, monomeric xylose can be employed as a feedstock via dehydration, hydrogenation or biological routes to produce other commercial products such as furfural, xylitol, and xylonic acid, which have huge market potential [8-10]. Currently, hydrolyzing poplar xylan to maximize xylan degradation (or xylose production) along with efficient enzymatic saccharification remains a problem, because under acidic conditions furfural can be continuously stripped out from pentose sugar [11-14]. An optimized and controllable hydrolysis reaction would successfully facilitate decomposition of xylan, which renders glucan vulnerable to enzymatic hydrolysis. Maximizing the production of xylose acquired from the acidic media of poplar xylan is a priority both for enhancing the capability of enzymatic hydrolysis and as a means of capitalizing on valuable commercial xylose products.

Among acidic pretreatment methods, acetic acid (HAc) a recyclable and cheap catalyst is as effective as mineral acids [14, 15]. Besides, acetic acid is cost-effective, safe to operate and easy to recover, especially being capable of high-efficient recycling by a simple vacuum distillation, which can yield over $75 \%$ recovery from the crude biomass hydrolysate and a yield up to $98 \%$ acetic acid recovery could be further realized by the formation of azeotrope (water-HAc) [15]. Our previous work on poplar and corncob biomass illustrated the efficacy of HAc in converting xylan to xylooligosaccharides (XOS). Additionally, we found HAc was effective in releasing glucose from corncob, while it was ineffective in achieving higher glucose yield from poplar due to its recalcitrance nature $[11,16]$. Studies on HAc biomass pretreatment focusing on the xylose production report temperatures between 100 and $150{ }^{\circ} \mathrm{C}$ as optimal operating condition [17-20]. Nonetheless, in the case of poplar relatively high temperatures of pretreatment were implemented for xylan degradation resulting in a reduction of the cellulose crystallinity, which has been demonstrated by our previous study [11]. During the catalytic reaction, the hydronium ions in acids promote the cleavage of glycosidic bonds present in the xylan, liberating free xylose that can be detected in the liquid phase. However, the occurrence of undesired parallel reactions can also take place, which are involved in secondary losses such as the dehydration of pentoses to furfural, along with the subsequent condensation (e.g., humins), resinification (e.g., resinous products) or decomposition [21-24]. To this end, monitoring the hydrolytic reaction in situ to minimize the formation of furfural is of great importance.

In addition, many acidic heterogeneous catalysts have been involved in biomass conversion. Recently, Mao et al. [14] developed a seawater-based furfural process co-existing with $\mathrm{HAc}$ steam and $\mathrm{FeCl}_{3}$, resulting in $72.9 \%$ furfural production and $79.5 \%$ lignin removal. For a more efficient enzymatic hydrolysis, the effects of $\mathrm{FeCl}_{3}, \mathrm{CuCl}_{2}$, and $\mathrm{AlCl}_{3}$ on the pretreated corn stover have been assessed. Results suggest that metal chloride salts display superior performance than $\mathrm{H}_{2} \mathrm{SO}_{4}$ at the same reaction condition [25]. Commonly, various acids including Lewis acids can be used to increase the hydrolytic reactivity during the acid hydrothermal fractionation (low pH) [1]. Besides, ions such as $\mathrm{Fe}^{3+}$ and $\mathrm{Al}^{3+}$ showed stronger cation exchange capacity than $\mathrm{H}^{+}$, being capable of coordinating to the oxygen atoms of the carbohydrate and enhancing the removal of xylan during pretreatment, leading in sugar gains for enzymatic digestibility [26-28]. Among reported catalysts, $\mathrm{FeCl}_{3}$ is preferably selected for grass/herb pretreatment, such as corncob, corn stover, and rice straw owing its nontoxic, low-cost and high selective nature [29-32]. Due to the strong acidity and oxidative power $\left(E^{\circ}=0.77 \mathrm{~V}\right.$ for $\left.\mathrm{Fe}^{3+} / \mathrm{Fe}^{2+}\right)$, the $\mathrm{FeCl}_{3}$-catalyzed biomass conversion process could be a promising technology that needs further investigation [2]. Moreover, Ogura et al. [33] achieved $90 \%$ of the theoretical ethanol yield during the fermentation by Saccharomyces cerevisiae after pretreatment with the $[\mathrm{BMIM}] \mathrm{Cl} / \mathrm{HCl}+\mathrm{FeCl}_{3}(4.8 \mathrm{wt} \%)+$ acetone-water system and subsequent saccharification, which suggests that enough water washing on pretreated biomass would eliminate the detrimental effects of soluble catalysts and 
lignocellulose-derived inhibitors on microbial growth. Additionally, it is expected to recover ferric chloride by adjusting $\mathrm{pH}$ with sodium hydroxide until the formation of ferric hydroxide precipitation. Then vacuum filtration could be used to separate and recover ferric hydroxide solid. Furthermore, the recovered ferric chloride can participate in Fenton reaction for the disposal of wastewater [34]. However, so far there have been limited studies combining inorganic salts in the aqueous acetic acid pretreatment of hardwood (e.g., poplar). The presence of higher lignin content creates hindrance for the effective dissolution of lignocellulosic biomass [35]. For this reason, implementation of metal salts and HAc in poplar xylan hydrolysis shows potential in enhancing hemicellulose sugar recovery and enzymatic efficiency of cellulose.

In this study, we report an integrated approach to use $\mathrm{HAc}$ as aqueous reaction media employing $\mathrm{Fe}$ ions as catalyst to explore a sustainable alternative for the effective recovery of hemicellulosic sugar (mainly xylose) from poplar and for promoting glucan recovery and delignification. Specifically, the $\mathrm{Fe}$ ions-assisted HAc fractionation was designed for efficient degradation of poplar xylan and release of xylose into the hydrolysate for further downstream processing. First, the effects of different $\mathrm{Fe}$ species $\left(\mathrm{Fe}^{2+}, \mathrm{Fe}^{3+}, \mathrm{Fe}^{8 / 3+}\right)$ on poplar xylan degradation were investigated. In addition, we systematically investigated the combined effect of $\mathrm{Fe}^{3+}$ and HAc on xylose production, glucan recovery, and lignin removal. Based on experimental data, a plausible mechanism of $\mathrm{Fe}^{3+}$ and HAc stimulating the xylose production was proposed.

\section{Results and discussion}

\section{Influence of different iron species on poplar xylan} degradation in aqueous HAc media

This section was designed to investigate the effectiveness of different Fe species on poplar xylan degradation in the presence of HAc solution. To further examine the fact that Fe ions could increase the xylan degradation, three different $\mathrm{Fe}$ salts, including trivalent $\mathrm{Fe}$ salt $\mathrm{FeCl}_{3}$, divalent $\mathrm{FeSO}_{4}$, and iron oxide $\mathrm{Fe}_{3} \mathrm{O}_{4}$ were explored. To eliminate the interference of $\mathrm{Fe}$ ion concentration levels, the Fe ion concentrations were selected in the range of 0.02$0.08 \mathrm{wt} \%$ based on $\mathrm{FeSO}_{4}, \mathrm{Fe}_{3} \mathrm{O}_{4}$, and $\mathrm{FeCl}_{3}$, respectively.

The reaction was carried out with $6.5 \%$ HAc solution at a temperature of $170{ }^{\circ} \mathrm{C}$. The fate of poplar xylan was determined by quantifying the yield of XOS (X2-X6), xylose and furfural. As shown in Fig. 1, in the cases of $\mathrm{FeSO}_{4}$ and $\mathrm{Fe}_{3} \mathrm{O}_{4}$, increasing the concentration of $\mathrm{Fe}$ ions made little contribution to xylan degradation to chemicals (XOS, xylose, and furfural). By contrast, the potential xylan was found to continuously increase from 58.7 to $75.0 \%$ as $\left[\mathrm{Fe}^{3+}\right]$ increased from 0.02 to $0.08 \mathrm{wt} \%$,

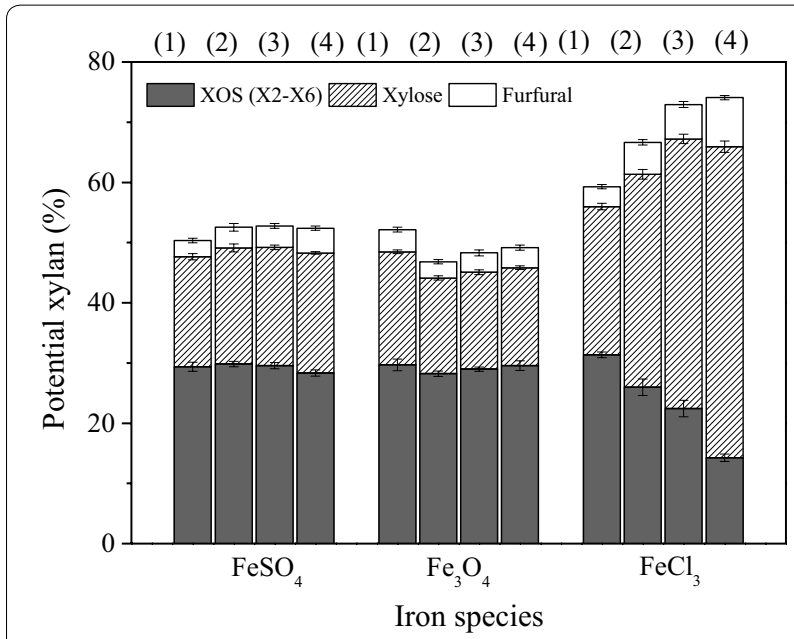

Fig. 1 Effects of various iron species, i.e., $\mathrm{FeSO}_{4}, \mathrm{Fe}_{3} \mathrm{O}_{4}$ and $\mathrm{FeCl}_{3}$, on production of XOS (X2-X6), xylose and furfural in aqueous HAc media. (all concentration in wt\%, unless otherwise stated) (1) 0.02 wt\%; (2) 0.04 wt\%; (3) 0.06 wt\%; (4) 0.08 wt $\%$ of $\mathrm{Fe}^{2+}, \mathrm{Fe}^{8 / 3+}$, and $\mathrm{Fe}^{3+}$

indicating that high concentrations of $\mathrm{FeCl}_{3}$ caused more xylan conversion. $\mathrm{FeCl}_{3}$ exerted different effects on XOS, xylose, and furfural production during the hydrolysis process. For instance, it was observed that XOS yields declined from 31.0 to $14.4 \%$, while the generated xylose and furfural increased from $24.2 \%$ and $3.4 \%$ to $52.3 \%$ and $8.3 \%$, respectively, after being treated by the elevated concentration of $\mathrm{Fe}^{3+}$ salt. These results suggest that $\mathrm{Fe}^{3+}$ could promote the decomposition of xylan and further degrade oligosaccharides into monosaccharides and other by-products, such as furfural [1,36]. Overall result indicate that $\mathrm{Fe}^{3+}$ salt exhibit better performance on wood xylan degradation than that of $\mathrm{Fe}^{2+}$ and $\mathrm{Fe}^{8 / 3+}$ salts, which is consistent with the result related to corn stover pretreatment by inorganic salts [32]. Notably, Yan et al. [37] also reported that $\mathrm{Cl}^{-}$exerted stronger effects on the hemicelluloses degradation, indicating the interaction behavior or combination between salts cations and anions were eye-catching that cannot be ignored.

\section{Influence of $\mathrm{Fe}^{3+}$ concentration on xylose-hydrolysate recovery $(\mathrm{XHR})$}

The influence of $\left[\mathrm{Fe}^{3+}\right]$ ranging from 0.02 to $1.32 \mathrm{wt} \%$ on poplar xylan degradation was also investigated with a concentration of $6.5 \%$ HAc. As illustrated in Fig. 2a, the impacts of $\mathrm{Fe}^{3+}$ as an enhancer of HAc on xylose production, generating by-products XOS and furfural during xylan conversion process were rigorously examined. It was observed that xylose yield increased from 25.0 to $73.9 \%$ as $\left[\mathrm{Fe}^{3+}\right]$ ratio increased from 0.02 to $0.25 \mathrm{wt} \%$, but a further increase of $\left[\mathrm{Fe}^{3+}\right]$ to $1.32 \mathrm{wt} \%$ decreased 
the yield (8.8\%). Similarly, the potential xylan showed an increasing trend, then decreasing with the maximum value of $91.1 \%$ at $0.25 \mathrm{wt} \%$ of $\left[\mathrm{Fe}^{3+}\right]$, indicating faster rate of xylose degradation than the production rate of furfural. Meanwhile, when $\left[\mathrm{Fe}^{3+}\right]$ reached $0.25 \mathrm{wt} \%$, XOS decreased to zero, indicating that $\left[\mathrm{Fe}^{3+}\right]$ could accelerate the decomposition of dissolved oligomeric xylose into monomeric xylose [32]. In the same way, the observed decrease in xylose yield demonstrated that increasing $\left[\mathrm{Fe}^{3+}\right]$ ratio favored the xylose formation, but an excessive $\mathrm{Fe}^{3+}$ resulted in more degradation products derived from monomeric xylose. Additionally, furfural yield dropped from 32.5 to $29.3 \%$ as $\left[\mathrm{Fe}^{3+}\right]$ increased from 0.66 to $1.32 \mathrm{wt} \%$. Liu and Wyman [38] also reported that the dosage of $0.8 \% \mathrm{FeCl}_{3}$ could accelerate furfural resinification and condensation. Similarly, Mao et al. [39] found that the catalysts $\mathrm{FeCl}_{3}$ and $\mathrm{HAc}$ co-catalyzing hydrolysis of corncob promoted the formation of furfural (67.9\%) but paid less attention to extracting xylose. Taken together, results illustrate that at the optimal concentrations of $0.17 \mathrm{wt} \%$ and $0.25 \mathrm{wt} \%\left[\mathrm{Fe}^{3+}\right]$, HAc media enabled XHR generate maximum xylose yields of $72.5 \%$ and $73.9 \%$, respectively.

$\mathrm{pH}$ can be described as an indicator of the stability of a hydrolysis system, as it depends on the buffering capacity of the biomass or reaction itself [40]. When different concentrations of $\mathrm{Fe}^{3+}$ salt were added $(0.02-1.32 \mathrm{wt} \%)$ to the HAc media, $\mathrm{pH}$ variations as a function of $\left[\mathrm{Fe}^{3+}\right]$ prior to and immediately after the pretreatment were also recorded. The $\mathrm{pH}$ value corresponding to each added $\mathrm{Fe}^{3+}$ concentration is displayed in Fig. 2b. It was observed that consistent $\mathrm{pH}$ decreasing trend $(\Delta=1.4$ $\mathrm{pH}$ units) occurred as $\left[\mathrm{Fe}^{3+}\right]$ increased from 0.02 to $1.32 \mathrm{wt} \%$, indicating the presence of $\mathrm{Fe}^{3+}$ could contribute an enhancement in the acid strength of the aqueous acetic acid solution. Notably, the highest xylose production can be obtained at the initial $\mathrm{pH}$ value around 1.3 corresponding to $0.25 \mathrm{wt} \%$ concentration of $\mathrm{Fe}^{3+}$ which has proven to be preferable for the effective pretreatment. Nonetheless, following hydrolysis, prehydrolysis $\mathrm{pH}$ values increased compared to initial $\mathrm{pH}$ prior to pretreatment. For instance, as presented in Fig. $2 \mathrm{~b}$, the $\mathrm{pH}$ value increased up to $0.5 \mathrm{pH}$ units after the hydrolysis while adding $0.25 \mathrm{wt} \%\left[\mathrm{Fe}^{3+}\right]$ into the reaction media. In general, a low $\mathrm{pH}$ will drive the pretreatment and the ash buffering capacity will mitigate the reduction in $\mathrm{pH}$ that results from addition of acid. Notably, some minerals such as $\mathrm{KCl}, \mathrm{K}_{2} \mathrm{HPO}_{4}$, and $\mathrm{K}_{2} \mathrm{SO}_{4}$ in biomass could realize the $\mathrm{pH}$-mediated abirritation [41]. In a separate study, Wu et al. [27] reported that $\mathrm{pH}$ decreased from 5.7 to 4.5 after autohydrolysis of waste wheat straw while increasing concentrations of $\mathrm{FeCl}_{3}(0-20 \mathrm{mM})$, suggesting the buffering capacity of wood poplar is stronger than that of agricultural plants, which needs further investigation. Aqueous solutions of $\mathrm{Fe}^{3+}$-HAc (0.25 wt\% $\left[\mathrm{Fe}^{3+}\right]$ ) are acidic ( $\mathrm{pH}$ 1.3). To assess whether or not the xylan conversion was dominated by the acidity of Brønsted acid, control experiments using acid to adjust $\mathrm{pH}$ in aqueous HAc with an identical proton concentration were implemented. Results show that the potential xylan
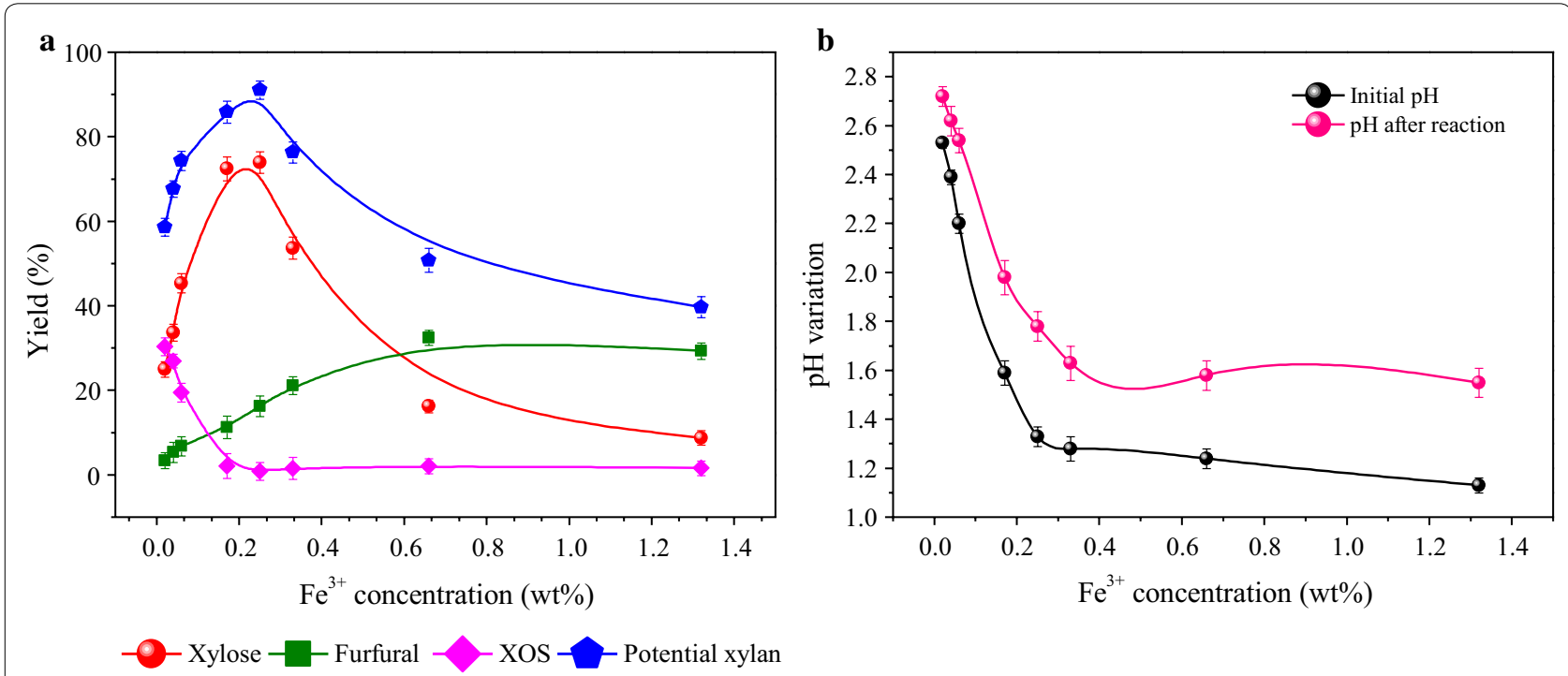

Fig. 2 Process optimization of sugar release after $\mathrm{Fe}^{3+}$-assisted $\mathrm{HAc}$ pretreatment. a Effects of Fe ${ }^{3+}$ concentration on the fate of hemicellulose in aqueous HAc media pretreated at $170{ }^{\circ} \mathrm{C}$ for $27 \mathrm{~min}$. $\mathbf{b} \mathrm{pH}$ variations as a function of added Fe ${ }^{3+}$ concentrations in the presence of $\mathrm{HAc}$ prior to and immediately after the pretreatment 
(91.1\%) with $\mathrm{Fe}^{3+}-\mathrm{HAc}$ was significantly higher than that with $\mathrm{pH}$-adjusted HAc (61.6\%) at the same acidity. Consistently, higher xylose $(73.9 \%)$ in the case of $\mathrm{Fe}^{3+}$ was obtained compared with $\mathrm{pH}$-adjusted solution (31.8\%). This illustrates the activity of $\mathrm{Fe}^{3+}$ in xylan conversion (especially xylose) was not solely governed by its Brønsted acidity. In a separate study, Marcotullio and De Jong [42] also reported that at the same $\mathrm{pH}$ aqueous $\mathrm{FeCl}_{3}$ was remarkably more effective than a strong acid solution. During the experiment, it was hypothesized that the coexistence of $\mathrm{FeCl}_{3}$ and $\mathrm{HAc}$ would take shape an insoluble ferric acetate compound. However, no precipitate was formed but the green liquid was observed during the xylose production in $\mathrm{Fe}^{3+}$-HAc media. It was proposed that the low concentration of $\mathrm{FeCl}_{3}$ and HAc may be problematic. Similarly, Zhang et al. [2] reported that adding a comparable amount of $\mathrm{HAc}$ into $40 \% \mathrm{FeCl}_{3}$ solution also resulted in clear liquid, given the assumption that the presence of $\mathrm{Cl}^{-}$and the deficiency of water in $\mathrm{FeCl}_{3}$ solution were not positive for the formation of the ferric acetate compound.

\section{Characteristics of hydrolysis $\mathrm{Fe}^{3+}$-HAc-residues}

Transition metal species have displayed superior performance on biomass hydrolysis. In this section, the catalytic characteristics of $\mathrm{Fe}^{3+}$ on poplar sawdust hydrolysis in HAc reaction media were examined. Herein, several representative conditions $\left(0.04 \mathrm{wt} \% \mathrm{Fe}^{3+}, 0.04,0.17\right.$, 0.25 , and $0.33 \mathrm{wt} \% \mathrm{Fe}^{3+}-6.5 \% \mathrm{HAc}$ ) were selected for the analysis. As a baseline, hydrolysis of poplar catalyzed by $0.04 \mathrm{wt} \%$ of $\mathrm{Fe}^{3+}$ without HAc was conducted. Table 1 presents the performances of poplar hydrolysis in varying conditions, including the fate of xylan (remaining xylan and xylan loss), composition of pretreated biomass and weight loss.

As shown in Table 1, the remaining xylan and glucan were $39.5 \%$ and $81.3 \%$, respectively. Furthermore, the lignin removal efficiency was $5.9 \%$, suggesting the weak catalytic effect of metal $\left(0.04 \% \mathrm{Fe}^{3+}\right)$ ion in lower lignin removal. However, removal of xylan increased from 60.5 to $80.1 \%$ in presence of co-catalysis of $0.04 \mathrm{wt} \% \mathrm{Fe}^{3+}$ and HAc solution. Simultaneously, the remaining glucan and lignin decreased from $81.3 \%$ and $94.1 \%$ to $80.3 \%$ and $68.1 \%$, respectively. These results indicate that HAc exhibit superior delignification than cellulose removal for poplar, which is consistent with the previous literature [39]. The role of $\mathrm{Fe}^{3+}$ dramatically enhanced glucan degradation (Table 1). For instance, the remaining lignin decreased from 68.1 to $44.5 \%$, while the remaining glucan decreased from 80.3 to $52.6 \%$ as $\left[\mathrm{Fe}^{3+}\right]$ increased from 0.04 to $0.33 \mathrm{wt} \%$. Mao et al. [14] also reported that $\mathrm{Fe}^{3+}$ was more effective in cellulose degradation than that of delignification. As well, the xylan loss and weight loss were obviously affected by the loading of $\mathrm{Fe}^{3+}$. From Table 1 , the xylan loss firstly decreased from $12.5 \%$ to $6-9 \%$ as $\left[\mathrm{Fe}^{3+}\right]$ increased from 0.04 to $0.25 \mathrm{wt} \%$ and then increased to $20.2 \%$ at $0.33 \mathrm{wt} \%$ of $\mathrm{Fe}^{3+}$. The reason for the increase of xylan loss at $0.33 \mathrm{wt} \%$ might lie in the fact that side reactions of furfural were promoted by excessive $\mathrm{Fe}^{3+}$, such as self-resinification and condensation of intermediates with furfural. While, weight loss continuously increased from 41.2 to $63.8 \%$ as $\left[\mathrm{Fe}^{3+}\right]$ increased from 0.04 to $0.33 \mathrm{wt} \%$. Specifically, it resulted in $100 \%$ xylan removal, $64.5 \%$ glucan retention and $42.5 \%$ delignification in the $0.25 \mathrm{wt} \% \mathrm{Fe}^{3+}$-HAc-pretreated residue. Taken together, it was exemplified that $\mathrm{Fe}^{3+}$-assisted HAc hydrolysis is effective on the catalytic formation of xylose, xylan degradation, glucan recovery, and delignification.

\section{Enzymatic hydrolysis efficiency of pretreated poplar}

For evaluation of the synergistic effects of $\mathrm{Fe}^{3+}$ and HAc on poplar sugar generation, pretreated residues underwent enzymatic saccharification. As shown in Fig. 3, the sugar yield reached $31.7 \%$ after hydrolysis for $96 \mathrm{~h}$ at $0.04 \mathrm{wt} \% \mathrm{Fe}^{3+}$ in absence of HAc. Huang et al. [11] achieved $23.7 \%$ saccharification yield from autohydrolyzed-poplar. Clearly, addition of $\mathrm{Fe}^{3+}$ during pretreatment resulted in 33.8\% improvement in saccharification efficiency. Additionally, the sugar yield also increased to $53.5 \%$ after $96 \mathrm{~h}$ at $0.04 \mathrm{wt} \% \mathrm{Fe}^{3+}$ with HAc, indicating

Table 1 Influence of different concentrations of $\mathrm{Fe}^{3+}$-assisted $\mathrm{HAc}$ media on characteristics of hydrolysis residue

\begin{tabular}{|c|c|c|c|c|c|c|}
\hline $\mathrm{Fe}^{3+}(w \mathrm{t} \%)$ & HAc & $\begin{array}{l}\text { Remaining } \\
\text { glucan (\%) }\end{array}$ & Remaining lignin (\%) & Remaining xylan (\%) & Xylan loss (\%) & Weight loss (\%) \\
\hline 0.04 & No & $81.3 \pm 1.5$ & $94.1 \pm 2.5$ & $39.5 \pm 2.4$ & $34.9 \pm 2.3$ & $31.1 \pm 2.4$ \\
\hline 0.04 & Yes & $80.3 \pm 2.4$ & $68.1 \pm 2.6$ & $19.9 \pm 1.6$ & $12.5 \pm 2.6$ & $41.2 \pm 1.8$ \\
\hline 0.17 & Yes & $69.9 \pm 2.6$ & $61.4 \pm 1.9$ & $7.3 \pm 1.6$ & $6.5 \pm 1.9$ & $51.5 \pm 1.6$ \\
\hline 0.25 & Yes & $64.5 \pm 1.9$ & $57.5 \pm 2.0$ & 0 & $8.9 \pm 2.2$ & $55.4 \pm 2.5$ \\
\hline 0.33 & Yes & $52.6 \pm 3.2$ & $44.5 \pm 2.9$ & 0 & $20.2 \pm 2.7$ & $63.8 \pm 3.5$ \\
\hline
\end{tabular}

Except for the conditions explained in the table, others were kept the same. $2.5 \mathrm{~g}$ of poplar sawdust was mixed with $25 \mathrm{~g}$ of aqueous reaction media. The concentration of HAc solution was $6.5 \%$, and the reaction temperature was maintained at $170{ }^{\circ} \mathrm{C}$ 


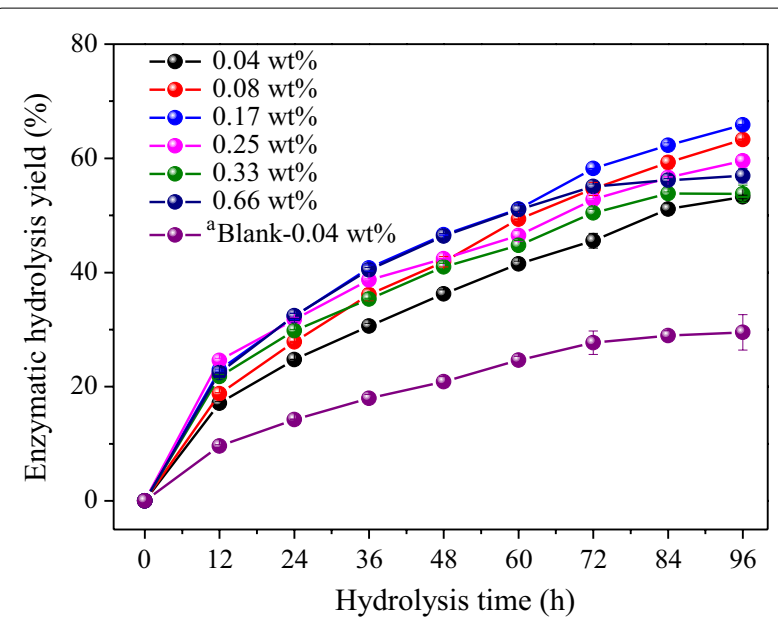

Fig. 3 Enzymatic hydrolysis of pretreated poplar xylan at different pretreated conditions for $96 \mathrm{~h}$ : different concentrations of $\mathrm{Fe}^{3+}$ in aqueous HAc media. ${ }^{2} \mathrm{Hydrolysis}$ by $0.04 \mathrm{wt} \% \mathrm{Fe}^{3+}$ without $\mathrm{HAC}$

that the synergistic interaction between these two catalysts played an essential role in enzymatic hydrolysis. From Fig. 3, as the $\mathrm{Fe}^{3+}$ concentration increased from 0.04 to $0.17 \mathrm{wt} \%$, the sugar yield increased from 53.5 to 65.9\%. Results obtained can be attributed to a higher concentration of $\mathrm{Fe}^{3+}$ resulting in stimulating release of reactive $\mathrm{H}_{3} \mathrm{O}^{+}$and facilitating the breaking of "blocking effect" of xylan in the lignocellulosic matrix [43-45]. However, further increasing the $\mathrm{Fe}^{3+}$ concentration to $0.66 \mathrm{wt} \%$ resulted in a decrease of sugar yield to $56.1 \%$ (Fig. 3). Chen et al. [46] also reported that a significant decrease of glucose conversion and a modest increase of cellobiose amount in saccharification was observed when the sulfuric acid concentration was increased from 3 to $15 \%$ for the pretreated rice straw. The phenomenon can be ascribed to the inhibitory effect on $\beta$-glucosidase led by lignin, and the greater hydrophobicity of pretreated biomass resulting in the enhanced adsorption of enzymes cocktails onto the lignin droplets at high acid concentration [46, 47]. Additionally, xylan degradation yields at 0.04 wt $\%$ and 0.17 wt $\% \mathrm{Fe}^{3+}$-HAc-residues were $80.1 \%$ and $92.7 \%$, providing further evidence for the increasing enzymatic efficiency.

As mentioned above, delignification and xylan removal increase the efficacy of enzymatic hydrolysis. Significantly improved sugar conversion (more than 65\%) could be achieved at the concentration of $0.17 \mathrm{wt} \% \mathrm{Fe}^{3+}$ in HAc media. However, the $108 \mathrm{~h}$ enzymatic hydrolysis efficiency of HAc-catalyzed poplar was only $51.0 \%$ [11]. Overall, for 0.17 and $0.25 \mathrm{wt} \% \mathrm{Fe}^{3+}$ inclusion into HAc hydrolysis resulted in $72.5 \%$ and $73.9 \%$ XHR, and $65.9 \%$ and $60.3 \%$ saccharification efficiency, respectively.

\section{Fractionation of biomass streams and mass balances}

The comprehensive data set of this research can provide the mass flow of poplar biomass components during $\mathrm{Fe}^{3+}$-assisted HAc pretreatment and subsequent enzymatic hydrolysis. Mass balances for glucan, xylan, and lignin at two different concentrations of $\mathrm{Fe}^{3+}(0.17$ and $0.25 \mathrm{wt} \%$ ) were tracked, which may give practical advice and feedback about process validity. As observed in Fig. 4, starting with 100 g poplar, the vast majority of the xylan was extracted and degraded into soluble xylose in the liquid stream after $\mathrm{Fe}^{3+}{ }_{-} \mathrm{HAc}$ pretreatment. As well, up to $40 \%$ of the lignin was solubilized in the liquid fraction, while only a small portion of glucan was converted into dissolved glucose, the majority being retained in the pretreated solids and subjected to enzymatic hydrolysis for fermentable sugars production. Figure $4 \mathrm{a}$ illustrated that a total amount of $12.7 \mathrm{~g}$ of xylose and $22.8 \mathrm{~g}$ of glucose were harvested from liquid streams during the whole process of $0.17 \mathrm{wt} \% \mathrm{Fe}^{3+}$-HAc hydrolysis coupled with enzymatic saccharification, which correspond to the yields of $72.2 \%$ and $66.8 \%$ for XHR and enzymatic efficiency. At the concentration of $0.25 \mathrm{wt} \% \mathrm{Fe}^{3+}$ in HAc media, the overall recoveries were $72.7 \%$ and $60.3 \%$ for XHR and saccharification, respectively (Fig. $4 \mathrm{~b}$ ). Considering the maximum xylose yield, we select the point of $0.25 \mathrm{wt} \%$ $\mathrm{Fe}^{3+}$ in HAc media for further verification experiment. Taken together, mass balance of poplar biomass illustrates the efficacy of $\mathrm{Fe}^{3+}$-assisted HAc pretreatment on lignin carbohydrate complex for production of fermentable sugars.

\section{Evaluation of different chloride-based salts on poplar xylan degradation in aqueous $\mathrm{HAc}$ media}

To evaluate the contribution of chloride ion to the catalytic hydrolysis, a comparison of different chloridebased salts for the depolymerization of poplar xylan was also carried out. Encouraged by the optimum concentration $\left(0.25 \mathrm{wt} \% \mathrm{Fe}^{3+}, 0.47 \mathrm{wt} \% \mathrm{Cl}^{-}\right)$for xylose production, further the same concentration of $\mathrm{Cl}^{-}$was considered for other salts (Fig. 5). As shown in Fig. 5, $\mathrm{KCl}$ and $\mathrm{NaCl}$ showed similar performance on the release of XOS, xylose and furfural, and only $\sim 24 \%$ of xylose could be obtained, which suggests that significant amounts of xylan are in the form of xylo-oligomers. At the concentration of $0.47 \mathrm{wt} \% \mathrm{Cl}^{-}$, the $\mathrm{FeCl}_{2}$ dosage or reaction temperature seemed not adequate to fully depolymerize wood xylan, and the yield of potential xylan was detected below $60 \%$. As a member of transition metals, $\mathrm{AlCl}_{3}$ was effective on the conversion of xylose to furfural (22.6\%). However, a yield of 


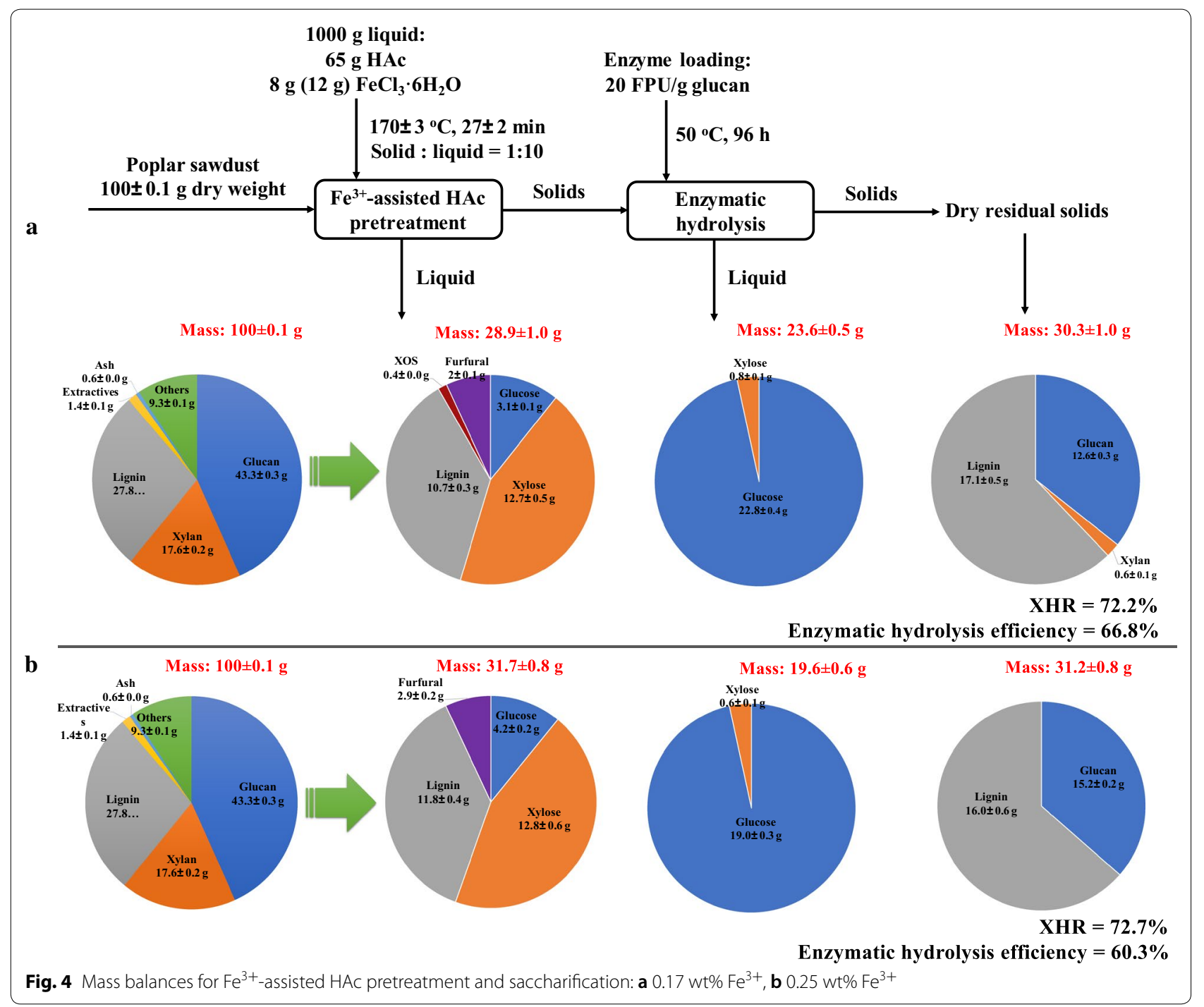

8.3\% XOS still remained in the hydrolysate, which indicates that the pretreatment process may require lower temperature $\left(<170{ }^{\circ} \mathrm{C}\right)$ for the decrease of furfural production, but longer reaction time $(>27 \mathrm{~min})$ for the effective conversion of XOS to xylose. When comparing different chloride-based salts, $\mathrm{FeCl}_{3}$ exhibited the greatest desired effect on xylose production. These data demonstrate that $\mathrm{Fe}^{3+}$ rather than $\mathrm{Cl}^{-}$that plays the dominant role in the catalysis enhancement to assist the hydrolysis of HAc.

\section{Mechanism of co-effects of HAc and $\mathrm{Fe}^{3+}$ on xylose production}

The pretreatment process for xylose production from poplar xylan involves several complicated processes, including swelling of poplar particles, liberation of acetylated and formylated xylose oligomers. Followed by, formation of precursor (xylose oligomers) of xylose and byproducts, acid-catalyzed formation of xylose and partial xylose degradation to furfural [14]. $\mathrm{HAc}$ and $\mathrm{FeCl}_{3}$ could impact the conversion process. Therefore, additional tests were conducted to understand the behaviors of these elements and find out catalytic effects on the hydrolysis process.

To understand the effect of catalysts on the hydrolysis pathway from wood xylan to xylose and furfural by $\mathrm{Fe}^{3+}$-HAc, beechwood xylan and xylose were treated under the same condition as poplar sawdust fractionation (Table 2). For instance, when xylan was treated with $0.08 \mathrm{wt} \%$ of pure $\mathrm{Fe}^{3+}$ (Table 2$)$, both xylose $(3.1 \mathrm{~g} / \mathrm{L})$ and furfural $(0.5 \mathrm{~g} / \mathrm{L})$ can be stripped out, indicating that certain amounts of $\mathrm{Fe}^{3+}$ can realize the further conversion of 
xylose to furfural. Addition of $6.5 \%$ HAc led to a significant increase in furfural generation (from 0.5 to $8.3 \mathrm{~g} / \mathrm{L}$, 17 -fold), as well as xylose (from 3.1 to $20.1 \mathrm{~g} / \mathrm{L}$, sixfold). This effect suggests that HAc displays strong catalytic performance on the formation of furfural. However, Yemis and Mazza [48] found that HAc yielded the lowest furfural production derived from xylan compared to strong mineral acids and other two organic weak acids (phosphoric acid and formic acid). The reason was expected to be different catalytic effect caused by varied process conditions (temperature, solid: liquid ratio and reaction time). When increasing $\left[\mathrm{Fe}^{3+}\right]$ (from 0.08 to $0.25 \mathrm{wt} \%)$, it was seen that the concentrations of xylose (from 20.1 to $23.5 \mathrm{~g} / \mathrm{L}$ ) and furfural (from 8.3 to $13.7 \mathrm{~g} / \mathrm{L}$ ) were increased. It was worthwhile to mention that the formation rate of xylose is lower at higher concentrations of $\mathrm{Fe}^{3+}$ (from 0.08 to $0.25 \mathrm{wt} \%$ ), indicating the faster degradation of xylose to furfural.

To confirm the above results, further xylose degradation experiments were conducted. When xylose was treated with $0.08 \mathrm{wt} \%$ of pure $\mathrm{Fe}^{3+}$ (Table 2), a comparatively higher amount of furfural was detected thus verifying that direct catalysis of xylose degradation via $\mathrm{Fe}^{3+}$ was easier and more efficient than of xylan. According to Yang et al. [49] a higher furfural yield from xylose than with pure xylan could be attributed to interference from other components in xylan. Addition of $6.5 \%$ HAc (Table 2) seemed to contribute less to the hydrolysis of xylose and the formation of furfural compared with those catalyzed solely by $\mathrm{Fe}^{3+}$. Likewise, hydrolysis of xylose with HAc alone (Table 2) resulted in low xylose degradation and hence, low furfural production. As shown in Table 2, with the increasing concentration of $\mathrm{Fe}^{3+}$ from

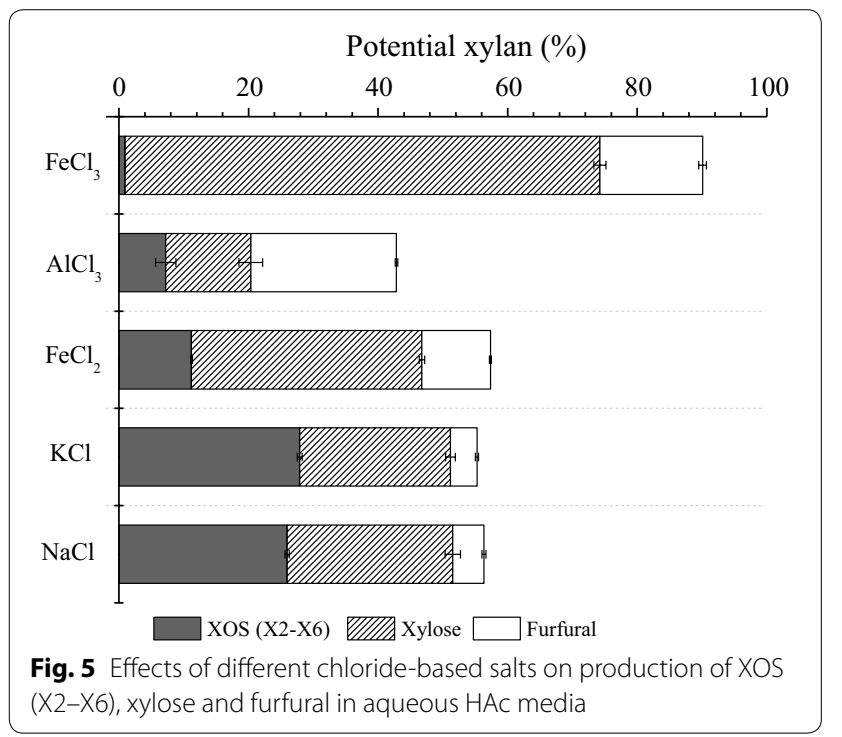

\begin{tabular}{|c|c|c|c|c|}
\hline \multirow[t]{2}{*}{ Reactant } & \multirow[t]{2}{*}{$\mathrm{Fe}^{3+}(w t \%)$} & \multirow[t]{2}{*}{ HAc (\%) } & \multicolumn{2}{|c|}{$\begin{array}{l}\text { Product concentration } \\
\text { (g/L) }\end{array}$} \\
\hline & & & Xylose & Furfural \\
\hline \multirow[t]{4}{*}{ Xylan } & 0.08 & No & $3.1 \pm 0.5^{\mathrm{a}}$ & $0.5 \pm 0.1$ \\
\hline & No & 6.5 & $13.9 \pm 0.3^{\mathrm{a}}$ & $5.9 \pm 0.4$ \\
\hline & 0.08 & 6.5 & $20.1 \pm 0.9^{a}$ & $8.3 \pm 0.2$ \\
\hline & 0.25 & 6.5 & $23.5 \pm 1.3^{\mathrm{a}}$ & $13.7 \pm 0.7$ \\
\hline \multirow[t]{4}{*}{ Xylose } & 0.08 & No & $59.3 \pm 2.6^{b}$ & $13.1 \pm 0.8$ \\
\hline & No & 6.5 & $70.5 \pm 0.8^{b}$ & $8.7 \pm 0.3$ \\
\hline & 0.08 & 6.5 & $54.3 \pm 1.84^{b}$ & $14.5 \pm 0.4$ \\
\hline & 0.25 & 6.5 & $19.8 \pm 0.6^{b}$ & $22.9 \pm 1.0$ \\
\hline
\end{tabular}

All the experiments were conducted at $170^{\circ} \mathrm{C}$ for $27 \mathrm{~min}$, and the initial concentration of xylan or xylose is $100 \mathrm{~g} / \mathrm{L}$

${ }^{\text {a }}$ Amounts of xylose production in the media

${ }^{b}$ Amounts of xylose remained in the media

0.08 to $0.25 \mathrm{wt} \%$ in xylose hydrolysis, remaining xylose concentration decreased from 54.3 to $19.8 \mathrm{~g} / \mathrm{L}$ and furfural concentration increased from 14.5 to $22.9 \mathrm{~g} / \mathrm{L}$. The results indicate that higher catalyst loading of $\mathrm{Fe}^{3+}$ is beneficial to facilitate the conversion of xylose to furfural, consistent with the results obtained from the hydrolysis of xylan. With respect to reaction rate, the rate of xylose decomposition was higher than that of furfural formation, suggesting that the co-catalysis of $\mathrm{Fe}^{3+}$-HAc significantly accelerated the xylose degradation, whose effect was greater than that of furfural production. It means that the degraded products of xylose contain other valueadded chemicals, such as aldehydes, dihydroxyacetone, acids, etc. [50]. In this experiment, decreasing furfural yield was not observed because the reaction time was not long enough for the occurrence of side reactions. In the opinions of Yemis and Mazza [48], a higher concentration of xylose and the presence of furfural would collide with each other, leading to a higher char yield. Additionally, a larger concentration of xylose was susceptible to undertake loss reactions, including successive condensation reactions with furfural and intermediates of xylose transformation [51].

\section{Conclusions}

$\mathrm{Fe}^{3+}$-assisted HAc hydrolysis of poplar xylan not only promoted XHR, but also enhanced the xylan degradation, delignification and glucan release. An overall process for XHR coupled with enzymatic hydrolysis was developed. Optimized conditions obtained the xylose yields of $72.5 \%$ and $73.9 \%$ at concentrations of $0.17 \mathrm{wt} \%$ and $0.25 \mathrm{wt} \%$ $\left[\mathrm{Fe}^{3+}\right]$ in HAc media. For enzymatic hydrolysis, a significantly improved sugar conversion (from 51.0 to $65.9 \%$ ) 
was achieved compared with HAc alone. Catalytic mechanisms were verified by employing model compounds of xylan and xylose. This study provides a deep understanding of the metal-organic hydrolytic conversion of wood polysaccharides to valuable products.

\section{Methods}

\section{Material}

A fast-growing poplar tree (3 years old) was harvested from the Jiangsu province in China. The wood sample was ground to pass through a 20 -mesh size screen $(<0.85 \mathrm{~mm})$, air-dried, homogenized in a single lot, and stored at room temperature. The moisture content of milled sawdust was approximately $10 \%$ based on total wet biomass weight. The composition of the poplar sawdust is glucan (43.3\%), xylan (17.6\%), acid-insoluble lignin (3.7\%), acid-soluble lignin (24.2\%), and ash content (0.6\%) by dry weight. $\mathrm{HAc}, \mathrm{FeCl}_{3} \cdot 6 \mathrm{H}_{2} \mathrm{O}, \mathrm{FeSO}_{4} \cdot 7 \mathrm{H}_{2} \mathrm{O}, \mathrm{Fe}_{3} \mathrm{O}_{4}$, sulfuric acid and xylan (from beechwood, $>90 \%$ xylose residues) used in the experiments were analytical reagents without further purification. Xylose, xylobiose (X2), xylotriose (X3), xylotetraose (X4), xylopentaose (X5), and xylohexaose (X6) were purchased from Shanghai Yikuo Instrument Co., Ltd. (Shanghai, China), and were used as standards.

\section{Experimental procedure for conversion}

A series of experiments were carried out in a sealed $30 \mathrm{~mL}$ stainless steel tube reactor using diluted HAc as the catalyst in presence of different species of $\mathrm{Fe}$ ions. The biomass was thoroughly mixed with a certain amount of HAc and varying concentrations of Fe species in the digester and then pre-impregnated for $1 \mathrm{~h}$ at room temperature. Based on our previous optimization, the reaction temperature, time and HAc concentration were chosen to be $170{ }^{\circ} \mathrm{C}, 27 \mathrm{~min}$ and $6.5 \%(\mathrm{v} / \mathrm{v})$, respectively [11]. In each experiment, the reactor was loaded with an amount of feedstock equivalent to $2.5 \mathrm{~g}$ of dry matter. To ensure the homogeneous distribution of aqueous solution into the granular poplar, a liquid-to-solid ratio of 10:1 was used. After the pretreatment, the solid was thoroughly washed with water to remove the residual catalysts.

Following pretreatment, enzymatic hydrolysis was carried out at $5 \%(\mathrm{w} / \mathrm{v})$ for $96 \mathrm{~h}$. The recovered solids were mixed with $50 \mathrm{mM}$ sodium citrate buffer at $\mathrm{pH} 4.8,0.2 \%$ $(\mathrm{w} / \mathrm{v})$ tetracycline, and the cellulose enzyme (C2730, Celluclast $^{\circledR} 1.5 \mathrm{~L}$, Novozymes Inc.). The enzyme loading was $20 \mathrm{FPU} / \mathrm{g}$ glucan at $50{ }^{\circ} \mathrm{C}$ and $150 \mathrm{rpm}$ in an orbital shaker (New Brunswick) [11]. Samples were taken periodically from the reaction mixture at $12 \mathrm{~h}$ intervals and centrifuged at 10,000 rpm for $5 \mathrm{~min}$ to detect the released glucose and cellobiose. For the quantification of fermentable sugars during enzymatic hydrolysis, the supernatants in the samples were diluted and followed by filtration through a $0.22 \mu \mathrm{m}$ syringe filter prior to high-performance liquid chromatography (HPLC) analysis.

\section{Analytical methods and calculations}

The chemical compositions of all the material were determined according to the standard laboratory analytical procedures developed by the National Renewable Energy Laboratory [52]. The moisture content of the sample was measured by an infrared moisture meter (FD-720, KETT). Monosaccharides and furfural were analyzed by HPLC (Agilent 1260 series, Agilent Technologies, Santa Clara, CA, USA) equipped with a refractive index detector and Aminex Bio-Rad HPX-87H column using $0.05 \mathrm{M} \mathrm{H}_{2} \mathrm{SO}_{4}$ at a flow rate of $0.6 \mathrm{~mL} / \mathrm{min}$ and column temperature of $55^{\circ} \mathrm{C}$. Xylooligosaccharides were determined using an HPAECPAD (Dionex ICS-5000) equipped with a carbopac PA-200 as the anion-exchange column and the separation method used herein was reported elsewhere [53]. Briefly, separation was achieved via gradient elution using mobile phase of $0.1 \mathrm{M} \mathrm{NaOH}$ and $0.5 \mathrm{M} \mathrm{NaOAc}$ containing $0.1 \mathrm{M} \mathrm{NaOH}$.

The xylose, XOS, furfural yield, enzymatic efficiency, remaining glucan and xylan, xylan loss and weight loss were calculated according to the following equations.

$$
\begin{aligned}
& \text { Xylose yield }(\%)=\frac{\text { xylose }[\mathrm{g}] \text { in supernatants }}{\text { xylan }[\mathrm{g}] \text { in raw material }} \times 100 \\
& \text { Furfural yield }(\%)=\frac{\text { furfural }[\mathrm{g}] \text { in supernatants }}{\text { xylan[g]in raw material }} \times 100
\end{aligned}
$$

$$
\begin{aligned}
& \text { XOS yield (\%) } \\
& =\frac{\text { sum of all XOS in supernatants (DP } 2-6)[\mathrm{g}]}{\text { xylan }[\mathrm{g}] \text { in raw material }} \times 100
\end{aligned}
$$

Enzymatic efficiency (\%)

$$
\begin{aligned}
& =\frac{(\text { glucose }+ \text { cellobiose } \times 1.05)[\mathrm{g}] \times 0.9}{\text { glucan }[\mathrm{g}] \text { in pretreated solids }} \times 100 \\
& \text { Remaining glucan }=\frac{\text { glucan }[\mathrm{g}] \text { in residue }}{\text { glucan }[\mathrm{g}] \text { in raw material }} \times 100 \% \\
& \text { Remaining xylan }=\frac{\text { xylan }[\mathrm{g}] \text { in residue }}{\text { xylan }[\mathrm{g}] \text { in raw material }} \times 100 \%
\end{aligned}
$$

Potential xylan $=($ xylose yield + furufral yield

$$
+ \text { XOS yield) } \times 100 \%
$$

Xylan loss $=(1-$ remaining xylan

$$
- \text { potential xylan) } \times 100 \%
$$




\section{Weight loss \\ $=\left(1-\frac{\text { mass of dried residue }[\mathrm{g}]}{\text { raw material }[\mathrm{g}]}\right)$}

$\times 100 \%$.

\section{Abbreviations}

HAc: Acetic acid; XHR: Xylose-hydrolysate recovery; XOS: Xylooligosaccharides; X2: Xylobiose; X3: Xylotriose; X4: Xylotetraose; X5: Xylopentaose; X6: Xylohexaose.

\section{Acknowledgements}

The work was supported by the National Key R\&D Program of China (2017YFD0601001). The authors also acknowledge the Priority Academic Program Development of Jiangsu Higher Education Institutions (PAPD) and the Doctorate Fellowship Foundation of Nanjing Forestry University for supporting the work presented in this paper.

\section{Authors' contributions}

$\mathrm{KXH}$ developed the idea for the study, performed the research, data analysis and prepared the manuscript. JMG helped to carry out the enzymatic hydrolysis. LD and YX helped to revise the manuscript. All authors read and approved the final manuscript.

\section{Funding}

The work was supported by the National Key R\&D Program of China (2017YFD0601001).

\section{Availability of data and materials}

All data generated and analyzed in this study are included in this published article.

\section{Ethics approval and consent to participate}

Not applicable.

\section{Consent for publication}

Not applicable.

\section{Competing interests}

The authors declare that they have no competing interests.

\begin{abstract}
Author details
${ }^{1}$ Key Laboratory of Forestry Genetics \& Biotechnology (Nanjing Forestry University), Ministry of Education, Nanjing 210037, People's Republic of China.

2 Jiangsu Co-Innovation Center of Efficient Processing and Utilization of Forest Resources, Jiangsu Province Key Laboratory of Green Biomass-based Fuels and Chemicals, College of Chemical Engineering, Nanjing Forestry University, Nanjing 210037, People's Republic of China. ${ }^{3}$ Joint BioEnergy Institute, 5885 Hollis Street, Emeryville, CA 94608, USA. ${ }^{4}$ Biomass Science and Conversion Technology, Sandia National Laboratories, 7011 East Avenue, Livermore, CA 94551, USA.
\end{abstract}

\section{Received: 1 Auqust 2019 Accepted: 5 October 2019} Published online: 17 October 2019

\section{References}

1. Kim TH, Ryu HJ, Oh KK. Low acid hydrothermal fractionation of Giant Miscanthus for production of xylose-rich hydrolysate and furfural. Bioresour Technol. 2016;218:367-72.

2. Zhang HD, Li N, Pan XJ, Wu SB, Xie J. Oxidative conversion of glucose to gluconic acid by iron(III) chloride in water under mild conditions. Green Chem. 2016;18:2308-12.

3. vom Stein T, Grande PM, Leitner W, de Maria PD. Iron-catalyzed furfural production in biobased biphasic systems: from pure sugars to direct use of crude xylose effluents as feedstock. ChemSusChem. 2011;4:1592-4.
4. Wang CB, Chang Y, Zhang LX, Pang MY, Hao Y. A life-cycle comparison of the energy, environmental and economic impacts of coal versus wood pellets for generating heat in China. Energy. 2017;120:374-84.

5. Jeong H, Park YC, Seong YJ, Lee SM. Sugar and ethanol production from woody biomass via supercritical water hydrolysis in a continuous pilotscale system using acid catalyst. Bioresour Technol. 2017;245:351-7.

6. Trajano HL, Pattathil S, Tomkins BA, Tschaplinski TJ, Hahn MG, Van Berkel GJ, Wyman CE. Xylan hydrolysis in Populus trichocarpa $\times$ P. deltoides and model substrates during hydrothermal pretreatment. Bioresour Technol. 2015;179:202-10

7. Zhao C, Zou ZS, Li JS, Jia HL, Liesche J, Chen SL, Fang H. Efficient bioethanol production from sodium hydroxide pretreated corn stover and rice straw in the context of on-site cellulase production. Renew Energy. 2018;118:14-24.

8. Fiorentino G, Ripa M, Ulgiati S. Chemicals from biomass: technological versus environmental feasibility - a review. Biofuel Bioprod Biorefin. 2017;11:195-214.

9. Zhou X, Zhou XL, Xu Y. Improvement of fermentation performance of Gluconobacter oxydans by combination of enhanced oxygen mass transfer in compressed-oxygen-supplied sealed system and cell-recycle technique. Bioresour Technol. 2017;244:1137-41.

10. Sener C, Motagamwala AH, Alonso DM, Dumesic JA. Enhanced furfural yields from xylose dehydration in the gamma-valerolactone/water solvent system at elevated temperatures. ChemSusChem. 2018;11:2321-31.

11. Huang KX, Luo J, Cao R, Su Y, Xu Y. Enhanced xylooligosaccharides yields and enzymatic hydrolyzability of cellulose using acetic acid catalysis of poplar sawdust. J Wood Chem Technol. 2018;38:371-84.

12. Nimlos MR, Qian XH, Davis M, Himmel ME, Johnson DK. Energetics of xylose decomposition as determined using quantum mechanics modeling. J Phys Chem A. 2006;1 10:11824-38.

13. Peleteiro S, Santos V, Garrote G, Parajo JC. Furfural production from eucalyptus wood using an acidic ionic liquid. Carbohydr Polym. 2016;146:20-5.

14. Mao LY, Zhang L, Gao NB, Li AM. Seawater-based furfural production via corncob hydrolysis catalyzed by FeCl3 in acetic acid steam. Green Chem. 2013;15:727-37.

15. Huang KX, Luo J, Wu YW, Xu Y. beta-Factor based separation characteristics of bio-derived chemicals present in lignocellulosic hydrolysates using vacuum distillation. ACS Sustain Chem Eng. 2019;7:2406-13.

16. Zhang HY, Xu Y, Yu SY. Co-production of functional xylooligosaccharides and fermentable sugars from corncob with effective acetic acid prehydrolysis. Bioresour Technol. 2017;234:343-9.

17. Guo ZW, Ling Z, Wang C, Zhang XM, Xu F. Integration of facile deep eutectic solvents pretreatment for enhanced enzymatic hydrolysis and lignin valorization from industrial xylose residue. Bioresour Technol. 2018;265:334-9.

18. Pan XJ, Sano Y. Fractionation of wheat straw by atmospheric acetic acid process. Bioresour Technol. 2005;96:1256-63.

19. Zhang HX, Zhao X, Ding XF, Lei H, Chen X, An DM, Li YL, Wang ZC. A study on the consecutive preparation of D-xylose and pure superfine silica from rice husk. Bioresour Technol. 2010;101:1263-7.

20. Chen YF, Dong BY, Qin WJ, Xiao DG. Xylose and cellulose fractionation from corncob with three different strategies and separate fermentation of them to bioethanol. Bioresour Technol. 2010;101:6994-9.

21. Jin H, Liu XL, Ban YJ, Peng Y, Jiao WM, Wang P, Guo A, Li YS, Yang WS. Conversion of xylose into furfural in a MOF-based mixed matrix membrane reactor. Chem Eng J. 2016;305:12-8.

22. Karinen R, Vilonen K, Niemela M. Biorefining: heterogeneously catalyzed reactions of carbohydrates for the production of furfural and hydroxymethylfurfural. ChemSusChem. 2011;4:1002-16.

23. Morais ARC, Bogel-Lukasik R. Highly efficient and selective $\mathrm{CO}_{2}$-adjunctive dehydration of xylose to furfural in aqueous media with THF. Green Chem. 2016;18:2331-4.

24. Rose IC, Epstein N, Watkinson AP. Acid-catalyzed 2-furaldehyde (furfural) decomposition kinetics. Ind Eng Chem Res. 2000;39:843-5.

25. Kamireddy SR, Li JB, Tucker M, Degenstein J, Ji Y. Effects and mechanism of metal chloride salts on pretreatment and enzymatic digestibility of corn stover. Ind Eng Chem Res. 2013;52:1775-82.

26. Wang W, Yuan TQ, Cui BK. Fungal treatment followed by FeCl3 treatment to enhance enzymatic hydrolysis of poplar wood for high sugar yields. Biotechnol Lett. 2013;35:2061-7. 
27. Wu XX, Huang C, Tang W, Huang CX, Lai CH, Yong Q. Use of metal chlorides during waste wheat straw autohydrolysis to overcome the self-buffering effect. Bioresour Technol. 2018;268:259-65.

28. Charlet $L$, Tournassat C. Fe(II)-Na(I)-Ca(II) cation exchange on montmorillonite in chloride medium: evidence for preferential clay adsorption of chloride-metal ion pairs in seawater. Aquat Geochem. 2005;11:115-37.

29. Kim I, Rehman MSU, Kim KH, Han Jl. Generation of electricity from $\mathrm{FeCl} 3$ pretreatment of rice straw using a fuel cell system. Bioresour Technol. 2013;135:635-9.

30. Zhang $L X, Y u H B$, Wang P, Li Y. Production of furfural from xylose, xylan and corncob in gamma-valerolactone using $\mathrm{FeCl}_{3} \cdot 6 \mathrm{H}(2) \mathrm{O}$ as catalyst. Bioresour Technol. 2014;151:355-60.

31. Pei HS, Liu L, Zhang XQ, Sun JS. Flow-through pretreatment with strongly acidic electrolyzed water for hemicellulose removal and enzymatic hydrolysis of corn stover. Bioresour Technol. 2012;110:292-6.

32. Liu L, Sun JS, Cai CY, Wang SH, Pei HS, Zhang JS. Corn stover pretreatment by inorganic salts and its effects on hemicellulose and cellulose degradation. Bioresour Technol. 2009;100:5865-71.

33. Ogura K, Ninomiya K, Takahashi K, Ogino C, Kondo A. Pretreatment of Japanese cedar by ionic liquid solutions in combination with acid and metal ion and its application to high solid loading. Biotechnol Biofuels. 2014;7:120

34. Pignatello JJ, Oliveros E, MacKay A. Advanced oxidation processes for organic contaminant destruction based on the Fenton reaction and related chemistry. Crit Rev Environ Sci Technol. 2006;36:1-84.

35. Bu LX, Tang Y, Gao YX, Jian HL, Jiang JX. Comparative characterization of milled wood lignin from furfural residues and corncob. Chem Eng J. 2011;175:176-84.

36. Huijgen WJJ, Smit AT, de Wild PJ, den Uil H. Fractionation of wheat straw by prehydrolysis, organosolv delignification and enzymatic hydrolysis for production of sugars and lignin. Bioresour Technol. 2012;114:389-98.

37. Yan YJ, Li TC, Ren ZW, Li GZ. A study on catalytic hydrolysis of peat. Bioresour Technol. 1996;57:269-73.

38. Liu CG, Wyman CE. The enhancement of xylose monomer and xylotriose degradation by inorganic salts in aqueous solutions at $180^{\circ} \mathrm{C}$. Carbohydr Res. 2006;341:2550-6.

39. Mao LY, Zhang L, Gao NB, Li AM. FeCl3 and acetic acid co-catalyzed hydrolysis of corncob for improving furfural production and lignin removal from residue. Bioresour Technol. 2012;123:324-31.

40. Li YY, Jin YY. Effects of thermal pretreatment on acidification phase during two-phase batch anaerobic digestion of kitchen waste. Renew Energy. 2015;77:550-7.

41. Horhammer H, Dou C, Gustafson R, Suko A, Bura R. Removal of non-structural components from poplar whole-tree chips to enhance hydrolysis and fermentation performance. Biotechnol Biofuels. 2018;11:222.
42. Marcotullio G, De Jong W. Chloride ions enhance furfural formation from D-xylose in dilute aqueous acidic solutions. Green Chem. 2010;12:1739-46.

43. Hu JG, Arantes V, Saddler JN. The enhancement of enzymatic hydrolysis of lignocellulosic substrates by the addition of accessory enzymes such as xylanase: is it an additive or synergistic effect? Biotechnol Biofuels. 2011;4:36.

44. Ravindran R, Sarangapani C, Jaiswal S, Cullen PJ, Jaiswal AK. Ferric chloride assisted plasma pretreatment of lignocellulose. Bioresour Technol. 2017;243:327-34

45. Zhang HD, Wu SB. Generation of lignin and enzymatically digestible cellulose from ethanol-based organosolv pretreatment of sugarcane bagasse. Cellulose. 2015;22:2409-18.

46. Chen WH, Pen BL, Yu CT, Hwang WS. Pretreatment efficiency and structural characterization of rice straw by an integrated process of dilute-acid and steam explosion for bioethanol production. Bioresour Technol. 2011;102:2916-24.

47. Selig MJ, Viamajala S, Decker SR, Tucker MP, Himmel ME, Vinzant TB. Deposition of lignin droplets produced during dilute acid pretreatment of maize stems retards enzymatic hydrolysis of cellulose. Biotechnol Progr. 2007;23:1333-9.

48. Yemis O, Mazza G. Acid-catalyzed conversion of xylose, xylan and straw into furfural by microwave-assisted reaction. Bioresour Technol. 2011:102:7371-8.

49. Yang Y, Hu CW, Abu-Omar MM. Synthesis of furfural from xylose, xylan, and biomass using $\mathrm{AlCl}_{3}$ center $\operatorname{dot} 6 \mathrm{H}(2) \mathrm{O}$ in biphasic media via xylose isomerization to xylulose. ChemSusChem. 2012;5:405-10.

50. Mohan M, Banerjee T, Goud W. Hydrolysis of bamboo biomass by subcritical water treatment. Bioresour Technol. 2015;191:244-52.

51. Sievers C, Musin I, Marzialetti T, Olarte MBV, Agrawal PK, Jones CW. Acidcatalyzed conversion of sugars and furfurals in an ionic-liquid phase. ChemSusChem. 2009;2:665-71.

52. Sluiter JB, Ruiz RO, Scarlata CJ, Sluiter AD, Templeton DW. Compositional analysis of lignocellulosic feedstocks. 1. Review and description of methods. J Agric Food Chem. 2010;58:9043-53.

53. Xu Y, Fan L, Wang X, Yong Q, Yu SY. Simultaneous separation and quantification of linear xylo- and cello-oligosaccharides mixtures in lignocellulosics processing products on high-performance anion-exchange chromatography coupled with pulsed amperometric detection. BioResources. 2013;8:3247-59.

\section{Publisher's Note}

Springer Nature remains neutral with regard to jurisdictional claims in published maps and institutional affiliations.
Ready to submit your research? Choose BMC and benefit from:

- fast, convenient online submission

- thorough peer review by experienced researchers in your field

- rapid publication on acceptance

- support for research data, including large and complex data types

- gold Open Access which fosters wider collaboration and increased citations

- maximum visibility for your research: over $100 \mathrm{M}$ website views per year

At BMC, research is always in progress.

Learn more biomedcentral.com/submissions 